\section{Fetal tissue and increased funding for Parkinson's Disease}

Last month, as the US Senate weighed how much money to authorize for research agencies under the Department of Health and Human Services for fiscal year 1998 (FY98), some members lobbied for a new ban on the use of fetal tissue in studies.

This is the first time since President Bill Clinton lifted the ban in 1993 that antiabortion advocates and others opposed to the research have attempted to reinstate a ban.

In the end, the Senate voted $60-38$ against a new prohibition, but those opposed to fetal tissue use may get another chance to introduce a ban, since the legislation is due to come before a joint conference of the Senate and the U.S. House of Representatives by October 1 st.

The push for a new prohibition was prompted by a bill proposed by Morris K. Udall - a retired congressman with Parkinson's - which seeks $\$ 100$ million in new spending for Parkinson's research at the National Institutes of Health (NIH).

Larry Hoffheimer, Washington counsel for the National Parkinson Foundation (NPF), says that NIH money already supports two scientists active in the field of fetal tissue research: Curt Freed at the University of Colorado Health Sciences Center (Denver) and Warren Olanow at the Mt. Sinai Medical Center in New York. Some of the $\$ 100$ million would more than likely go to funding this type of research into the disease.

Although Clinton requested $\$ 13$ billion in spending for the FY98 NIH budget, including a $\$ 36$ million increase over FY97 spending on neuroscience research, the NPF wants funds set aside specifically for Parkinson's disease, says Hoffheimer.

For that to occur, the Udall bill has to pass the joint Senate/House conference. Hoffheimer says he's "hopeful" that the bill will pass, and that fetal tissue opponents will not succeed at that time. But Hoffheimer also notes that NIH director Harold Varmus has objected to "earmarking" funds for research priorities and to the Udall bill.

Alicia AuLt Washington, D.C.
Since a diagnostic test for hepatitis C became available in 1990, several industrialized nations have been quick to implement it in order to prevent transfusions of contaminated blood. Less clear is the policy for dealing with transfusion recipients that received blood prior to this date.

\section{The US recommends hepatitis C testing}

An advisory committee to the US Department of Health and Human Services recently recommended that anyone who received a blood transfusion before 1992 should be tested for the presence of hepatitis $C$ virus. It also recommended a focused "lookback" or tracing program, for those patients who received blood from donors now known to be positive for the virus, but whose donated blood might have tested negative in earlier, less sophisticated screenings.

The panel rejected the idea of a broader and more intensive lookback at donated blood prior to the introduction of screening tests because, according to bioethicist Arthur Caplan, who chaired the panel, the decentralized health care system in the US makes it hard to track recipients pre-1990. However, Caplan noted that other countries, such as the UK and Canada, could do this more effectively as a result of nationalized health care and more uniform record-keeping.

An estimated 290,000 Americans are believed to have been infected through blood transfusions prior to 1990 . The virus - which can result in severe liver damage and/or liver cancer - is also transmitted via contaminated needles, breast feeding and sexual intercourse. Around 20 percent of carriers develop cirrhosis of the liver within two decades of infection, requiring organ transplantation in the most severe cases, and 1-5 percent of carriers develop cancer of the liver after 20 years.

For those that do find they are hepatitis $C$ positive, they will also discover that the only drug which has any effect, alpha-interferon, works in a mere 20 percent of cases. In addition, a recent British Medical loumal study reported that alpha-interferon is almost always ineffective in patients with cirrhosis, and its side effects can be so severe that patients often refuse therapy. Fortunately, preliminary studies are showing that combining alpha-interferon with the nucleoside drug ribavirin appears to double its effectiveness. It is hoped that this may lead to a greater patient acceptability of interferon treatment. In the US, however, ribavirin is currently approved only for the treatment of a rare respiratory condition in children, meaning that it must be prescribed in an off-label capacity for hepatitis $\mathrm{C}$ patients.

The short-term therapeutic outlook for hepatitis $C$ looks bleak: there are very few new drugs in the pharmaceutical pipeline, and the prospects for vaccine development are even less promising. Furthermore, there is no animal model of the disease on which to test potential treatments. Nevertheless, people have a right to know if they carry the virus, and this is what the advisory committee confirmed.

MARLENE Cimons Washington, D.C.

\section{The UK tracks blood recipients}

Tracking persons at risk of hepatitis $\mathrm{C}$ infection because of contaminated blood transfusions is easier in the UK than in the US, but the effort is still tremendous, according to Angela Robinson, medical director of the National Blood Authority in England. The UK's "lookback" program, initiated in January of 1995 and about $60 \%$ complete, required all transfusion centers to seek out potentially contaminated donations prior to September 1991, when the screening mechanisms for the hepatitis $C$ virus were put in place.

Hospital records in the UK are maintained for 15 years - the US requires seven-year storage - so the chances of locating people at risk is higher in the UK, but since records sometimes get lost, the effort is never $100 \%$ effective, according to Robinson.

A telephone hot-line was opened in January of 1995 so that anyone concerned could contact the National Blood Authority. "People do get worried," says Robinson, "and require well-constructed advice." She estimates that there are roughly 3000 past recipients of contaminated blood products who are likely to still be alive, but stresses that the proportion of hepatitis $\mathrm{C}$ infections related to contaminated transfused blood is minute, contributing to only $1 \%$ of diagnosed cases in the UK. The largest risk factor appears to be intravenous drug use.

CHRIS DICKEY

New York 